Études bouriates, suivi de Tibetica miscellanea

\title{
Introduction
}

\section{Nikolay Tsyrempilov}

\section{(2) OpenEdition}

\section{Journals}

Electronic version

URL: https://journals.openedition.org/emscat/2486

DOI: 10.4000/emscat.2486

ISSN: 2101-0013

\section{Publisher}

Centre d'Etudes Mongoles \& Sibériennes / École Pratique des Hautes Études

\section{Electronic reference}

Nikolay Tsyrempilov, "Introduction", Études mongoles et sibériennes, centrasiatiques et tibétaines [Online], 46 | 2015, Online since 10 September 2015, connection on 13 July 2021. URL: http:// journals.openedition.org/emscat/2486 ; DOI: https://doi.org/10.4000/emscat.2486

This text was automatically generated on 13 July 2021.

(c) Tous droits réservés 


\title{
Introduction
}

\author{
Nikolay Tsyrempilov
}

\section{EDITOR'S NOTE}

Editors' note : Terms in Buryat have been transliterated according to official Buryat spellings provided by dictionaries.

Present-day scholarship on the Buryats, or Buryat-Mongols, consciously or otherwise considers the people in question and the areas they inhabit as a marginal part or periphery of the Mongolian or Russian worlds; the logic of this marginality is determined by the history of this ethno-cultural group formation at the civilizational juncture between Asia and Europe, and furthermore acquires its historical and cultural identity from this marginality. Indeed, most of the few Western Buryatologists approach their area specialization from one of two dominant perspectives. The majority of them initially had, and still have, an established basic interest in Russian studies or, to be precise, studies in Russian Siberia. ${ }^{1}$ In this perspective the Buryats are viewed as the largest indigenous people of Siberia, culturally and historically one of the most curious minorities of Asiatic Russia.

The second perspective runs through Mongolian (rarely Tibetan) studies, but even here the Buryats are seen only as a part (albeit an important one) of the larger Mongolian or Tibetan Buddhist worlds. ${ }^{2}$ It turns out that the Buryats are still being studied as a fragment of a larger picture, be it Mongolia, Russia, Tibetan Buddhism, Siberian Shamanism, and so forth.

However, this academic marginality should not necessarily be regarded as a flaw. One of the positive aspects is that Buryat studies attract a circle of researchers with specialization in various regions and disciplines, and Buryatology thus becomes a highly contextualized sphere. In many cases this contextualization may generate a multidimensional picture.

It is no less important to keep in mind that the Buryats are a classic case of an autoethnographic people, and it was in the middle of the 19th century that early Buryat 
chroniclers first attempted to describe their own people by imitating modern European ethnographic accounts. ${ }^{3}$ However, it was in the early 20th century that the school of Buryatology started to take shape thanks to the outstanding efforts of the first ethnographers and historians of Buryat origin.

In early Soviet times this school, based in Buryatia, included many famous names, such as Bazar Baradiin, Tsyben Zhamtsarano, Gombozhap Tsybikov, and Mikhail Bogdanov. Almost all these brilliant scholars were purged in the 1930s. ${ }^{4}$ Due to the post-WWII political configuration (especially the deterioration in USSR-PRC relations during the 1950s), ${ }^{5}$ Buryat studies have drifted away from Mongolian studies. The Buryats began to be viewed as a group with weak links with the larger Mongolian world, whose 'real history' starts with the 1917 Bolshevik Revolution. Postcolonial discourse becomes dominant but exclusively in the Marxist interpretation of historical materialism. Buryatology in the USSR evolved separately from the rest of the world, and this is still true for Buryat studies of Buryatia. This special issue of EMSCAT represents a resolute step towards overcoming this protracted isolation.

Today, apart from the school of Buryatology of Ulan-Ude which is now based in the Institute for Mongolian, Buddhist and Tibetan studies, Department of History and Culture of Buryatia of Buryat State University, Buryat Academy of Mongolia, there are no other established and systematic centres of Buryat studies in other parts of the world. Nonetheless, there are a few experts in various aspects of Buryat studies in different universities and academies of China, Mongolia, Europe and the USA. This issue of EMSCAT is the first attempt at a compilation of papers by Buryatologists of different countries and regions, including the Republic of Buryatia. Readers will judge how successful this attempt is, but I would like to believe that it is a sign of growing interest in Buryat studies in the world.

The six papers selected for this issue are written in the framework of different approaches and source bases and are yet to a certain degree united by a few overarching problems : specifically, problems of interpretation of what is regarded as traditional, and the problem of identity arising from the interaction between traditional and modern, local and global, in the domains of physical health, religious ritual, culture, mass media, genealogy or geographical space.

In his contribution to the issue Battsengel Natsagdorj illustrates the complexity of ethnic identity and political loyalty in the 17th century Mongol world. The focus of his paper are the Buryat migrants to Western Mongolia, known as Hariad, who for a long time were counted as a part of the Mongolian dominating sub-ethnic group of the Halh. The Hariad never followed other Buryat clans who returned to live under Russian administration, but managed to retain their common identity, albeit under a different name.

The ideas of norms and the normative in both traditional and modernizing Soviet Buryat society are discussed in Sodnompilova and Bashkuev's papers. Marina Sodnompilova scrupulously analyses what was considered deviation from the norm in the domains of mental and physical health, or simply disease. The normative order, as seen in the traditional Buryat worldview, depends on a delicate balance between the worlds of human beings and those of deities and spirits. This traditional understanding of diseases and their causes is not necessarily a property of the past. These views demonstrate surprising endurance in contemporary Buryat society. 
Vsevolod Bashkuev also raises the problems of what was normative in the sphere of health and hygiene, but his narrative concerns early Soviet representations of the Buryats as a model Socialist nation able to serve as a reference point for other peoples of Asia. He scrutinizes the goals and points of reference of the scientific research conducted by the Soviet professionals in medicine and social hygiene and their German counterparts in Buryat-Mongolia in the 1920-30s. Bashkuev traces the cultural and scientific shifts that took place in early Soviet Russia in the sphere of eugenics and approaches to healthcare and led to concrete policies in Buryat-Mongolia. Contrasting the German approach to healthcare policies with the politically charged Soviet conception of the degeneracy of backward peoples, Bashkuev shows how the Soviet conception of positive eugenics gradually prevailed due to the Bolsheviks' conviction in the gradual social progress of the Soviet people.

Caroline Humphrey examines the traditional Buryat understanding of geographic space and spatial order, contrasting it with the centre/periphery hierarchical pattern of the Russian state. The traditional worldview of the Buryats implied alternative views of what constituted the centre and the periphery, how geographical space was organized and the logic underlying this organization. Reflecting on the ideas stated in Sodnompilova's paper on revitalization of the older concepts in the new isolation of the Buryat villages in the super-centralized Russia of our days, Humphrey shows how this traditional vision of spatial order challenges the state models.

Melissa Chakars tackles the important question of how effectively the Soviet authorities utilized TV and radio as an ideological instrument in their attempt to modernize the Buryat society and create a new type of identity. One of the important issues Chakars raises is the contradictory nature of this process when a local TV channel, by drawing attention to the problems of the local community, challenged the official narrative concerning the formation of Soviet national identity. Another significant point is that although the authorities established total control over mass media, the actual perceptions of their messages were out of their control. It is obvious, the author concludes, that these messages generated alternative views that might differ significantly from what was expected.

Justine Quijada and Eric Stephen ponder the issues of the local and the global, using the example of the International Shaman's Conference and Tailgan, or collective prayer, organized by the Tengeri Shaman's Association annually from 2002 on Olkhon Island of Lake Baikal. The paper's main purpose is to show what multiple perceptions of the performance reveal about the individual participants in the event. Their point of comparison is the audience that attends smaller rituals that are regularly organized at the headquarters of Tengeri in Ulan-Ude. It predominantly consists of Buryats rather than Russians or other ethnic groups, and the concepts of 'tradition' and 'authenticity' are articulated during these ceremonies even if outsiders often question this authenticity. The analysis of the survey data gathered during the Tailgan in the summer of 2012 shows how divergent audiences can be and how their motivations can differ. What is more important is how the organizers of the ceremony shift the accent from the local and specific to the global and universal aspects of shamanism to appeal to a diverse audience.

While the papers offer diverse perspectives on the same problems concerning the past and present of the Buryats, this issue invites readers of EMSCAT into a process of 
developing a new analytical field which may potentially lead to a re-consideration of approaches in Mongolian and Tibetan studies.

\section{BIBLIOGRAPHY}

Belka, L.

2014 Mandala a dějiny : Bidija D. Dandaron a burjatský buddhismus (Brno, Masarykova univerzita),

$170 \mathrm{p}$.

Bernstein, A.

2013 Religious Bodies Politic. Rituals of Sovereignty in Buryat Buddhism (University of Chicago Press), $280 \mathrm{p}$.

Chakars, M. A.

2014 The Socialist Way of Life in Siberia. Transformation in Buryatia (Central European University Press, Budapest - New York), 296 p.

Ippei, S.

2014 The Roots Seekers : Shamanism and Ethnicity among the Mongol Buryats (Yokohama, Shumpusha Publishing), $576 \mathrm{p}$.

Kollmar-Paulenz, K.

2014 Systematically Ordering the World : the Encounter of Buriyad-Mongolian, Tibetan and Russian Knowledge Cultures in the 19th Century, in Philippe Bornet et al. (eds) L'orientalisme des marges : éclairages à partir de l'Inde et de la Russie (Revue Etudes de lettres, Université de Lausanne), pp. 123-146.

Manduhai, B.

2013 Tragic Spirits. Shamanism, Memory, and Gender in Contemporary Mongolia (University of Chicago Press), $336 \mathrm{p}$.

Montgomery, R. W.

2005 Late Tsarist and Early Soviet Nationality and Cultural Policy. The Buryats and their Language (The Edwin Mellen Press, Lewiston, Queenston, Lampeter), 347 p.

Rupen, R.

1956 Buryat intelligentsia, Far Eastern Quarterly 15(3), pp. 383-398.

Schorkowitz, D.

2001 Staat und Nationalitäten in Rußland: Der Integrationsprozeß der Burjaten und Kalmücken, 1822-1925 (Stuttgart, Franz Steiner), 616 p.

\section{NOTES}

1. This is true for the Buryatologists of Europe and the USA, most of whom study the Buryats as a part of the Russian world. Recent studies of different aspects of the Buryat history and religions published in the West include Chakars (2014), Montgomery (2005), Schorkowitz (2001). 
2. The attempts to view the Buryats in the context of the larger Mongolian world are usually based on the example of the Buryat diaspora of Mongolia, as in the prominent works of Manduhai (2013) and Ippei (2014). As for recent studies that place the Buryats in the framework of the Tibetan Buddhist world see Bernstein (2013).

3. A recent study by Karenina Kollmar-Paulenz shows that some of the $19^{\text {th }}$ century Buryat chronicles that provide a systematic taxonomy of the Buryat shamanist tradition bear obvious traces of the influence of Russian ethnographic scholarship. See Kollmar-Paulenz (2014).

4. A brilliant, and still uncontested, account of the early $20^{\text {th }}$ century Buryat intelligentsia has been given by Robert Rupen (1956).

5. In 1956, after Nikita Khrushchev's visit to the PRC, the Buryat-Mongolian Autonomous Soviet Socialist Republic was hastily renamed the Buryat Autonomous Soviet Socialist Republic, and the Buryat-Mongol people officially changed their name to Buryat. The reason for these changes was purely political.

\section{AUTHOR}

\section{NIKOLAY TSYREMPILOV}

Nikolay Tsyrempilov is Head of Department of History of Buryatia of the Buryat State University (Ulan-Ude, Republic of Buryatia). The subject of his academic interest is the history of Buddhism in Tibet, Mongolia and Russia. Among his monographs are 'From Tibet Confidentially. Secret Correspondence of the Thirteenth Dalai Lama to Agvan Dorzhiev, 1911-1925' (LTWA, 2013), 'Buddizm i Imperia : Buriatskaia Buddiiskaia sangha i Rossiiskoe gosudarstvo v XVIII-nach. XX vv.' (Buddhism and the Empire. Buriat Buddhist Sangha and Russian state in the 18th-early 20th c. Ulan-Ude, 2014). He is a member of Inner Asia Journal editorial board, Brill's Inner Asia Archive and Brill's Eurasian Studies Library. In 2013-2014 he was a member of Princeton Institute for Advanced Study. 